\title{
THE IMPLEMENTATION OF ASSET MANAGEMENT CONCEPT IN EDUCATION INSTITUTION
}

\author{
Asep Sunandar \\ Department of Educational Management \\ State University of Malang, Indonesia \\ asep.sunandar.fip@um.ac.id
}

\author{
Djum Djum Noor Benty \\ Department of Educational Management \\ State University of Malang, Indonesia \\ dj.noor.benty@gmail.com
}

\begin{abstract}
Asset management concept has been implemented in many institutions including educational institution. The implementation of that concept in Indonesia is done by integrating it with education facility management. Educational institution is a non-profit organization that implies to the differences of asset management in an educational institution. This study explains the implementation of asset management in schools as well as problems and threats of asset management implementation. The research was conducted by case analysis in three schools in Batu City. The results explain that asset management in school was done by the headmaster, and helped by the vice of headmaster, the affair of school facilities and the school staffs. The apparent problems are the late help from government and the lack of participation of the society. The process of school asset management occurred in provision, inventory, placement, maintenance, and report. The process causes the assets school value not optimal.
\end{abstract}

Keywords: asset management, educational institution, the asset utility

\section{INTRODUCTION}

The implementation of asset management in the educational institution in Indonesia has not been familiar yet since the concept has not been massively implemented in the educational institution. The process of school asset management is done by using the principle of infrastructure management in which the process is only related to the providing, placing, maintaining, inventorying and reporting the asset. The weakness of the concept of infrastructure management occurring in the educational institution in Indonesia is this concept does not describe the value of the asset and its utility so that the utility is a lack of optimality.

Asset management can be explained as a process of providing, inventorying, recording the use and evaluation of asset utility to support the implementation of the activity and the achievement of organization goal1. Meanwhile, Sunandar explains that asset management is an effort done to optimize the potential of a certain asset to achieve the goal, mission, and vision of an organization2. Another explanation affirms the process of asset management; asset management is an effort to balance the risk and cost to find an optimal solution3. Based on the explanation of asset management, it can be stated that asset management is an effort to manage and improve the utility of a certain asset to reach the organization goal [1].

The implementation of asset management concept in educational institution cannot be equated with the business or industrial institutions since the status of an educational institution is a non-profit organization [2]. The school asset cannot be compared to the profit got by the school. Profit calculation done by the school cannot be accumulated in the form of nominal calculation or quantitative data. The profit of the education outcome generally has some characteristics such as long-term, qualitative, and not ascertainable. Long term means that the advantage cannot be relished right after the students finish one step of education; the school advantage is usually apparent around the next ten up to twenty years. Qualitative characteristic means the benefit that can be obtained by the school cannot be associated in the form of a number or descriptive data. A student that has graduated certain level of education should master some competencies like what has been stated in the curriculum. The characteristic is not ascertainable since the development of someone's career is determined by him/herself, effort, and the God destiny. Based on such cases, the school benefit cannot be ascertainable after processing the students' study.

Based on the characteristics of the educational institution, the implementation process and beneficial parameter of a certain asset in the school are different. If in the business or industrial institutions, the benefit value of the certain asset can be seen from the quality of the product resulted and the profit nominal got, the asset benefit can only be seen from the duration of the asset usage.

The asset management in the modern era cannot be done manually since the process is very detailed and needs high accuracy. Some management experts have developed a concept called as digital asset management (DAM). This concept is explained as a strategy to increase the asset utility and reduce the work flow and the time of process cycle [4]. The implementation of asset management is not only in the asset data entry but also on the updating the asset information system so that the information regarding the asset will always be updated.

In line with the characteristics of the educational institution and the renewal of asset management concept, the researchers view that it is necessary to study how the asset management concept should be implemented in the educational institution in Indonesia actually. The problems and the constraints regarding the implementation of the asset management should be known to make the school managers, and officials of education department can take a proper policy. 


\section{METHODS}

This research was conducted by using the qualitative approach with the type of case study. The data collection was done by using interview technique. The ones who were interviewed were the headmaster, the vice of headmaster for the field of infrastructure, and the school staffs of infrastructure. This research was conducted in the primary and secondary school levels in Batu City, East Java Province. The data analysis process was done in such stages as data display, condensation and taking conclusion [5].

\section{RESULT}

School asset management is an effort in optimizing the use of school resource to reach the optimum limit of certain asset function. The school asset is various; among one school to the other schools have a different asset. However, generally, the limitation of school asset can be classified into three types including current asset, fixed asset, and intangible asset.

The implementation of school asset management in the field has a difference depending on the headmaster's and teachers' view in optimizing the asset potential owned. The difference gives impact to the optimality of certain asset usage in the learning process. The data presented in this research will clarify the process of asset management applied in the schools becoming the research field so that a description of asset management pattern applied in the school can be found.

Table 1

Research Result Data

\begin{tabular}{|c|c|c|c|}
\hline $\begin{array}{c}\text { LOCATION } \\
\text { FOCUS } \\
\end{array}$ & Data of Elementary School & Data of Junior High School & Data of Senior High School \\
\hline $\begin{array}{l}\text { Asset } \\
\text { management } \\
\text { policy }\end{array}$ & $\begin{array}{l}\text { - Inventory, placement, and report } \\
\text { - Maintenance }\end{array}$ & $\begin{array}{l}\text { - Considering the law } \\
\text { - The management and the use of asset } \\
\text { were done by the vice of headmaster for } \\
\text { the field of infrastructure } \\
\text { - The headmaster was responsible } \\
\text { generally }\end{array}$ & $\begin{array}{l}\text { - Referring to the law of school asset } \\
\text { management } \\
\text { - The responsibility of school asset } \\
\text { with the report to the Education } \\
\text { Department }\end{array}$ \\
\hline $\begin{array}{l}\text { Implementation } \\
\text { of school asset } \\
\text { management }\end{array}$ & $\begin{array}{l}\text { - Headmaster became the caretaker } \\
\text { of asset management } \\
\text { - The process of asset provision from } \\
\text { the government and society }\end{array}$ & $\begin{array}{l}\text { - Arranging the schedule of asset usage } \\
\text { - The management was under the control } \\
\text { of the field of infrastructure }\end{array}$ & $\begin{array}{l}\text { - Asset need proposal } \\
\text { - Asset distribution } \\
\text { - Asset maintenance } \\
\text { - Asset assessment } \\
\text { - Allocating the fund from regional } \\
\text { and national school operational } \\
\text { funds to maintain and provide the } \\
\text { asset }\end{array}$ \\
\hline $\begin{array}{l}\text { The faced } \\
\text { constraints }\end{array}$ & $\begin{array}{l}\text { - The process of asset provision done } \\
\text { by the government was late. }\end{array}$ & $\begin{array}{l}\text { - The class asset was insufficient. } \\
\text { - The extracurricular property was } \\
\text { minimum. } \\
\text { - The laboratory of Natural Science and } \\
\text { Language was limited. }\end{array}$ & $\begin{array}{l}\text { - The lack of people's support } \\
\text { - The asset or property labeling } \\
\text { should be done manually. }\end{array}$ \\
\hline $\begin{array}{l}\text { Asset } \\
\text { maintenance }\end{array}$ & $\begin{array}{l}\text { - The teacher was responsible for the } \\
\text { asset in each class. } \\
\text { - The students used the assets based } \\
\text { on their needs. } \\
\text { - The society also maintained the } \\
\text { school assets. }\end{array}$ & $\begin{array}{l}\text { - The use of the asset was based on the } \\
\text { schedule. } \\
\text { - The maintenance was done routinely. } \\
\text { - Every student should be responsible for } \\
\text { the class asset. }\end{array}$ & $\begin{array}{l}\text { - The teachers were responsible for } \\
\text { the asset used. } \\
\text { - The students were involved in } \\
\text { maintaining the assets. } \\
\text { - The asset maintenance was done } \\
\text { periodically. }\end{array}$ \\
\hline $\begin{array}{l}\text { The outside } \\
\text { help }\end{array}$ & $\begin{array}{l}\text { The society has a role in term of } \\
\text { safety and the school asset } \\
\text { provision. }\end{array}$ & $\begin{array}{l}\text { - Partnership with the business } \\
\text { institution. }\end{array}$ & - Partnership with alumni. \\
\hline
\end{tabular}

The process of asset management among the three education levels generally has similarity, but there are some different things as well among them. In the elementary school level, the asset management policy was started with inventory, placement, maintenance, report, and responsibility. The caretaker of the asset holistically was done by the headmaster, but specifically, the teachers and students were also responsible for the school assets they used. The process of asset maintenance was done by the teachers and students helped by the society. In the level of elementary school, generally, parents still accompanied their children in the school, so that they could participate to maintain the school asset during the spare time. The constraint that aced by the school in managing the asset was the late help from the government regarding the asset needed by the school. This case stimulated the school to make a partnership with around society and donator institution to fulfill the school needs.

The process of asset management in Junior High School level was done by considering the applied law. The provision and management of the asset of the country have been regulated in the Rule of Republic of Indonesia Government Number 54 Year 2010 about providing the asset/service of government, and the Law of RI Number 17, Year 2003 about the Country Financial, the Rule of Republic of Indonesia Government Number 27, Year 2014 about the Management of State/Local Asset. The process of asset management was done operationally by the vice of headmaster for the field of infrastructure while the headmaster became the general caretaker to the Education Department. The use of the asset in Junior High School was done based on the schedule that had been determined. The process of asset maintenance was 
done based on the schedule; the maintenance was done routinely, and every student was demanded to be responsible for the class asset. The constraint that was still faced was the limited asset of school to support the learning process such as classroom, laboratory, and the property of extracurricular activities. The effort to overcome any weaknesses was made by building a partnership with the other ones that can help the school.

The process of asset management in Senior High School was not far different from the process in the Elementary School and Junior High School. The asset management was done by considering the applied law. The vice of headmaster for the field of infrastructure is responsible operationally while the headmaster is responsible generally for the Office of Education Department. The process of asset management is done in some stages such as asset need proposal, asset distribution, asset maintenance, and asset assessment. After mapping the needs, fund allocation from BOSDA (Bantuan Operasional Sekolah Daerah/Regional School Operational Fund) and BOSNAS (Bantuan Operasional Sekolah Nasional/ National School Operational Fund) was done to maintain and provide the asset. The teachers and students also took a role in maintaining the asset used. Besides, the school also had a program of asset maintenance periodically. The constraints that were often faced by the school was the lack of support from the society due to the free school policy popularized by the regional government. The ones who managed the assets could not work optimally since the asset management system used was still manual. The other one who also helped the school in providing and maintaining the school assets was alumni association for many of the alumni of Senior High School who got a successful life.

\section{DISCUSSION}

Asset management is a management of the asset owned to make the use of asset value optimal. Certain view states that the asset management as a regular thing and certain structured process includes the whole life time of certain physical asset [6]. Asset management is an effort to regulate the asset usage and maintenance to reach the optimum level of the utility. The goal of asset management is to support the achievement and use of asset optimally [7]. Both opinions affirm the importance of asset management as an effort to get the optimal value of every asset owned.

The research results showed that the process of asset management in the educational institution was started by considering the law issued by the Indonesian government. The Rule of Home Affairs Ministry Number 17 the year 2007 about the Technical Guideline of Regional Asset Management Article 4 (1) states that the management of regional asset is done based on the functional base, legal certainty, transparency, efficiency, accountability, and the value certainty8. That rule affirms that the regional asset management should consider the functional aspect including the utility value of asset, the legal certainty in which the process of provision until the use of the asset does not violate the rule that has been applied, transparency-openness- accountability is a principle to make the asset management is far from the corruption and collusion practices. This certainty can be explained as the suitability of price and utility value of the asset to support in achieving the organization goal.

Asset management has a high advantage since every organization activity must need asset. The process of asset management generally consists of asset maintenance, increase in the asset value, the asset provision based on the reasonable price [9]. Another finding showed the case which was not far different from such asset management process. The process of asset management in the educational institution in Indonesia is started by data basing the need, providing the asset, distributing the asset, maintaining the asset, and assessing the asset. The asset maintenance and assessment is a part of asset management process, while the data base and distribution of need are the realization of the asset provision based on the reasonable and appropriate price, and the asset assessment is a monitoring process to see the effectiveness of certain asset owned.

The process of asset management occurring in the schools in Batu city like what had been found in this research can be stated that the school asset management was done directly by the headmaster helped by the vice of headmaster for the field of infrastructure as well as the staffs of the school asset.

The finding in one of the schools reported that the structure of school asset management in the State Elementary School of Ngaglik 01 Batu was the headmaster became the full caretaker of the asset management, but there was another part of asset handled by the operator and helped by the field of infrastructure (property). Every asset coming was inventoried and listed in an asset book, and then it was reported to the Education Department and Regional Government of Batu so that the school asset could be managed well. That explanation affirms that the role of the school in managing the school asset was only in inventorying and reporting the asset owned by the Education Department. The asset management should not be only in term of inventorying and reporting to implement the asset management but also in term of asset need analysis, asset planning, asset provision process, asset maintenance, and assessment and finally, it comes to reporting the asset. The data complement regarding asset owned by an institution will help the regional government in taking a policy to provide or eliminate an asset.

Mechanism of asset reporting in Regional Government of Batu City was done by using a website of Information System of Asset Management in Batu City. The process of school asset management in Batu City relies on some rules, for example, is the Rule of the Ministry of Home Affairs Number 17 the year 2007 about the Technical Guideline of Regional Asset Management. Globally, the guideline of regional asset management is stated in the following rules: 1 . The regional head becomes the ruler of regional asset management; 2. Regional secretary becomes the manager of the regional asset; 3 . The helper of regional 
asset manager; 4 . The head of SKPD becomes the user of the regional asset.

The setting of asset management structure was done to make the process of asset management open, transparent, and accountable. The asset of a certain region or school will be audited by the Audit Board as a process of monitoring the use of regional budget allocation and the utility of the asset owned. The administration discipline and the appropriateness of the asset usage will support the effectiveness of regional government and school performance in running the development programs very much. The data which was resulted in the process of asset management also influenced the process of taking a decision [10].

The case explained above affirms that the asset management supports the effectiveness of performance and achievement of organizational goal. Asset management as an integration of all activities of an organization affirms that asset influences all activities of an organization. Asset management gives significant impact to the achievement of organization or institution in the future. The support potential of the asset is the key factor in implementing the activities of certain organization. The existence of asset becomes one of the important things in realizing the future success of an organization.

\section{CONCLUSION}

The paradigm of asset management should be changed; it is not only limited in the case of asset inventory, but it should be continued up to the assessment of school asset as well. This case is important since the asset value tends to decrease so that an effort to optimize the asset value is necessary.

The asset management is an important part of school management process; school asset has significant implication for the information of the asset owned and it can be a consideration in making a decision done by the school leader. Therefore, the policy of providing the school asset in the future can be more relevant based on the school need.

The school should make a partnership with the society, students' parents, regional government, and the private institutions to fulfill the school asset needs well. The partnership process is not only in term of providing the asset but also using the utility value of the asset.

\section{REFERENCE}

[1] Management A. Asset Management - an anatomy Asset Management - an anatomy. 2014, July.

[2] Sunandar, A., Benti D. N., Sumarsono, R. B. Measuring of Teacher Asset Value. 2016, 14, 14-16.

[3] Campbell J, Jardine AKS, McGlynn J. Asset Management Excellence: Optimizing Equipment LifeCycle Decisions.; 2011.

[4] Wager S. Digital asset management, media asset management, and content management: From confusion to clarity. J Digit Asset Manag. 2005;1(1):40-45. doi:10.1057/palgrave.dam.3640008.

[5] Miles M, Huberman M, Saldana J. Qualitative Data Analysis. Vol $\quad$ 1.; 2014 doi:10.1080/0140528790010406.
[6] Brown AOI, Kerry A, Craig W, Proceedings E, Issues C, Brown K. QUT Digital Repository: Asset Management and Governance: Analysing Vehicle Fleets in Asset- Intensive Organisations. 2008;2008:120.

[7] Campos J, Sharma P, Gabiria UG, Jantunen E, Baglee D. A Big Data Analytical Architecture for the Asset Management. Procedia CIRP. 2017;64:369-374. doi:10.1016/j.procir.2017.03.019.

[8] Infokum S, Binbangkum D. Mengingat 1. 2013:1-97.

[9] Trojanová M. Asset management as integral part of road economy. Procedia Eng. 2014;91(TFoCE):481486. doi:10.1016/j.proeng.2014.12.030.

[10] Brous P, Herder P, Janssen M. Towards Modelling Data Infrastructures in the Asset Management Domain. Procedia Comput Sci. 2015, 61, 274-280. doi:10.1016/j.procs.2015.09.215. 